\title{
ARAHAN DAN STRATEGI PENGEMBANGAN LAHAN SAWAH DI WILAYAH PESISIR PROVINSI KALIMANTAN BARAT
}

\section{Direction and Strategy for Wetland Ricefield Development in Coastal Region of West Kalimantan Province}

\author{
Yustian 1)*, Untung Sudadi2), dan Muhammad Ardiansyah2) \\ 1) Alumni Program Studi Ilmu Perencanaan Wilayah, Sekolah Pascasarjana IPB, Jl. Raya Darmaga, Gedung Andi \\ Hakim Nasoetion Kampus IPB Darmaga Bogor 16680 \\ 2) Departemen Ilmu Tanah dan Sumberdaya Lahan, Fakultas Pertanian IPB, Jl. Meranti Kampus IPB Darmaga \\ Bogor 16680
}

\begin{abstract}
The Coastal Development Region (DR) is the rice production center and supplier even for the three other DR area in West Kalimantan Province. By 2015, the Coastal DR inhabitant is predicted to be 2.29 million people. Assuming wetland ricefield conversion occurred at a rate of 30,000 ha year ${ }^{-1}$ and without addition of the raw land area, then rice supply for the regional area become deficit in 2016. Therefore, a comprehensive direction and strategy for wetland ricefield development is needed. This research aimed at to: (1) to identify potential lands, (2) to determine comparative and competitive advantages, (3) to determine land typology and cluster, and (4) to arrange spatial direction and strategy for wetland ricefields development in the Coastal DR. Spatial analysis identified potential lands for wetland ricefield development of 411,950 ha as part of 5,664,580 ha total Coastal DR area. Based on LQ and SSA analyses, two out of seven regencies/city in the Coastal DR were classified as prominent basis area, and four of them were categorized as "established cluster" for wetland ricefields development. Sambas and Kubu Raya regencies have the largest potential lands, performing as prominent basis area with developed agricultural activities, therefore they were prioritized for wetland ricefield development.
\end{abstract}

Keywords: Coastal development region, development direction and strategy, West Kalimantan Province, wetland ricefield

\begin{abstract}
ABSTRAK
Wilayah Pengembangan (WP) Pesisir merupakan sentra produksi beras bahkan penyuplai untuk tiga WP lainnya di Provinsi Kalimantan Barat. Pada tahun 2015, penduduk di WP Pesisir diperkirakan 2.29 juta jiwa. Bila terjadi konversi lahan basah 30,000 ha tahun ${ }^{-1}$ dan tanpa penambahan luas lahan baku sawah, ada indikasi berkurangnya suplai beras diluar WP Pesisir dan tahun 2016 bahkan mengalami defisit beras. Oleh karena itu, diperlukan arahan yang komprehensif dan strategi untuk pengembangan sawah sawah. Penelitian ini bertujuan untuk: (1) mengidentifikasi lahan potensial, (2) menentukan keunggulan komparatif dan kompetitif, (3) menentukan tipologi lahan dan klaster, dan (4) menyusun arah secara spasial dan strategi untuk pengembangan sawah lahan basah di WP Pesisir. Hasil analisis spasial diperoleh luasan lahan potensial 411,950 ha untuk pengembangan padi sawah dari 5,664,580 ha luas total WP Pesisir. Berdasarkan analisis LQ dan SSA ada lima dari tujuh kabupaten/kota sebagai wilayah basis pertanian padi, sedangkan analisis tipologi membentuk tiga klaster wilayah. Keseluruhan hasil analisis menunjukkan bahwa Kabupaten Sambas dan Kabupaten Kubu Raya adalah Kabupaten yang paling besar luas lahan potensialnya disusul oleh Kota, merupakan wilayah basis unggulan dan aktivitas pertaniannya yang sudah berkembang sehingga paling diprioritaskan untuk pengembangan kawasan padi sawah.
\end{abstract}

Kata kunci: WP Pesisir, arahan dan strategi pengembangan, Kalimantan Barat, padi sawah

\section{PENDAHULUAN}

Pengembangan wilayah di Provinsi Kalimantan Barat dibagi kedalam empat Wilayah Pengembangan (WP), yaitu WP Tengah, WP Pesisir, WP Antar Provinsi dan WP Antar Negara, sebagaimana dituangkan dalam Peraturan Daerah Kalimantan Barat No. 7 tahun 2008 tentang Rencana Pembangunan Jangka Panjang Daerah 2007-2027.

Wilayah Pengembangan (WP) Pesisir merupakan sentra produksi dan pemasok beras bahkan untuk tiga WP lainnya di Provinsi Kalimantan Barat. Namun, dengan asumsi Indeks Pertanaman (IP) $130 \%$, risiko gagal panen $5 \%$ per tahun dan terjadi konversi sawah dengan laju $9.8 \%$ per tahun, maka produksi padi di WP Pesisir pada tahun 2016 diprediksi mencapai 460,178 ton gabah kering giling (GKG). Hal ini akan mengakibatkan defisit 9,922 ton GKG dari kebutuhan konsumsi penduduk WP Pesisir sebesar 470,100 ton GKG. Apabila tidak diimbangi dengan ekstensifikasi pengembangan sawah, maka perannya sebagai pemasok beras bagi tiga WP lainnya juga akan berakhir pada tahun 2016 sehingga akan mengganggu kondisi ketahanan pangan di Provinsi Kalimantan Barat.

*) Penulis Korespondensi: Telp.+6282152095100; Email. yustianyusuf@gmail.com 
Hasil analisis Tim Peneliti Pemetaan Sumberdaya Lahan, Balai Besar Penelitian dan Pengembangan Sumberdaya Lahan Pertanian, Bogor (Hikmatullah et al., 2008) menunjukkan bahwa luas lahan potensial untuk pengembangan tanaman pangan lahan basah di Provinsi Kalimantan Barat mencapai 1,090,514 ha. Namun, penggunaan lahan sawah eksisting pada tahun 2012 hanya 307,016 ha, terdiri atas sawah beririgasi seluas 103,255 ha dan sawah non-irigasi seluas 203,761 (BPS Kalbar, 2012). Hal ini menunjukkan masih besarnya peluang untuk perluasan lahan sawah di Kalimantan Barat.

Kontribusi sektor pertanian mencapai 25\% dari total PDRB Provinsi Kalimantan Barat sebesar 60.48 trilyun rupiah (BPS Kalbar, 2012). Kontribusi tertinggi berasal dari sub-sektor tanaman pangan, disusul perkebunan, peternakan, perikanan dan kehutanan. Total produksi padi sawah kabupaten/kota yang berada di WP Pesisir mencapai 867,464 ton atau $68 \%$ dari total produksi padi sawah Kalimantan Barat sebesar 1,284,464 ton pada tahun 2012. Fakta ini mengindikasikan bahwa produksi padi di WP Pesisir lebih tinggi daripada WP lainnya.

Keberhasilan pengembangan lahan sawah di WP Pesisir diharapkan dapat meningkatkan pembangunan pertanian Kalimantan Barat, khususnya dalam hal peningkatan produksi padi untuk memenuhi kebutuhan konsumsi wilayah lokal maupun regional. Terkait hal itu, maka wilayah perencanaan dari wilayah pesisir dapat diambil secara kompromistis antara wilayah administratif dengan wilayah fungsional. Berdasarkan latar belakang tersebut, penelitian ini bertujuan: (1) mengidentifikasi lahan potensial untuk pengembangan pertanaman padi sawah, (2) mengetahui sentra produksi padi sawah berdasarkan keunggulan komparatif dan kompetitif, (3) mengetahui tipologi dan klaster tingkat perkembangan wilayah, serta (3) merumuskan arahan spasial dan strategi pengembangan padi sawah berbasis klaster di WP Pesisir Kalimantan Barat.

\section{BAHAN DAN METODE}

\section{Lokasi Penelitian}

Penelitian ini dilakukan di tujuh kabupaten/kota WP Pesisir Provinsi Kalimantan Barat, yaitu Kabupaten Sambas, Kota Singkawang, Kabupaten Bengkayang, Kabupaten Pontianak, Kabupaten Kubu Raya, Kabupaten Kayong Utara dan Kabupaten Ketapang.

\section{Bahan dan Alat}

Dalam penelitian ini digunakan data primer dan sekunder. Data primer diperoleh melalui observasi dan wawancara langsung di lokasi penelitian, sedangkan data sekunder diperoleh melalui penelusuran data spasial dan statistik di berbagai instansi pemerintah dan swasta, yaitu BPS, Dinas Pertanian Tanaman Pangan dan Hortikultura serta Bappeda Provinsi Kalimantan Barat, Badan Informasi Geospasial, Direktorat Jenderal Prasarana dan Sarana Pertanian Kementerian Pertanian RI, Direktorat Jenderal Planologi Kementerian Kehutanan RI dan SEAMEO BIOTROP Bogor. Untuk pengolahan data spasial digunakan software GIS dan Erdas Imagine, sedangkan pengolahan data statistik digunakan software MS Excell dan Statistica serta peralatan pendukungnya.

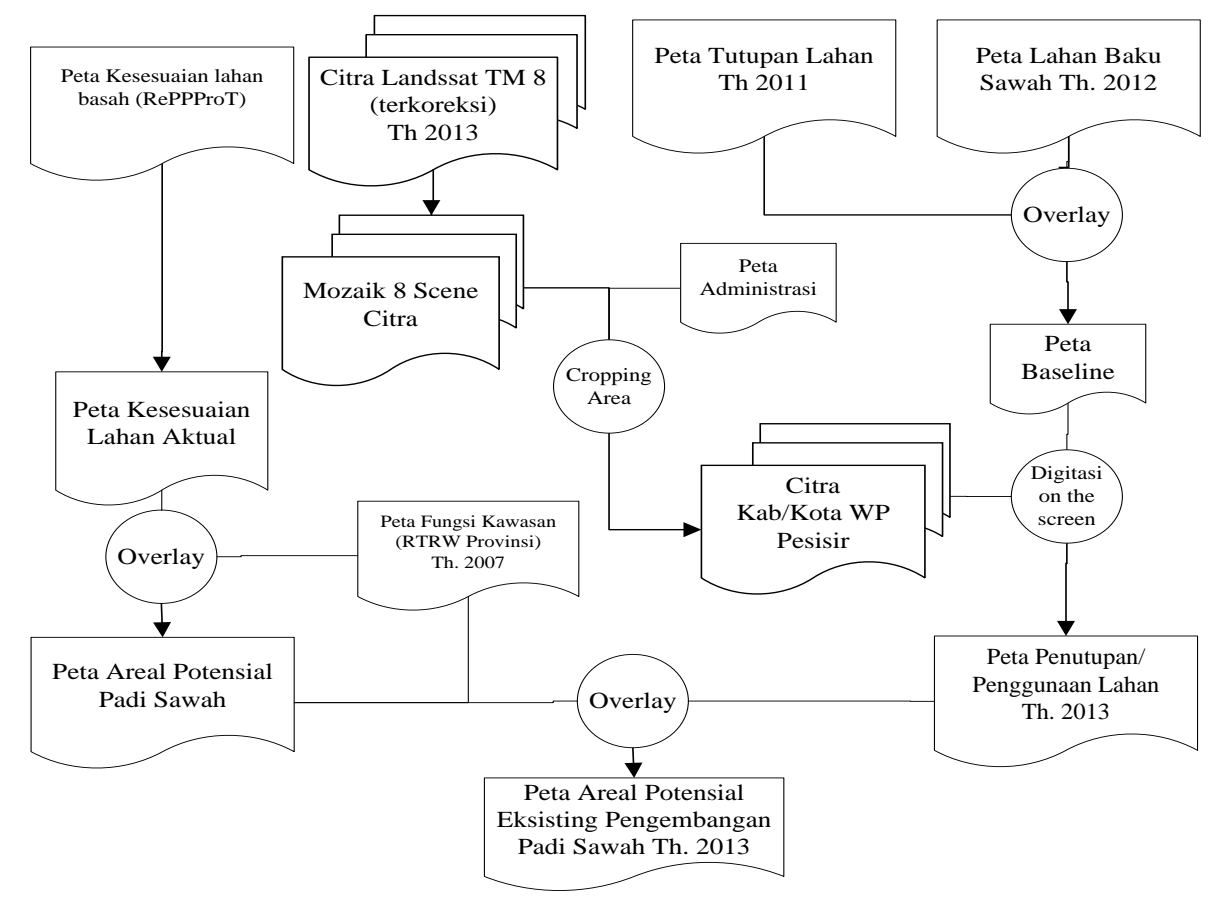

Gambar 1. Proses pembuatan peta areal potensial eksisting pengembangan padi sawah 


\section{Analisis Data}

\section{Analisis dan Identifikasi Areal Sawah Eksisting dan} Potensial

Analisis ini diawali dengan pembuatan peta baseline hasil union peta lahan baku sawah tahun 2012 dan peta tutupan lahan tahun 2011 dilanjutkan dengan interpretasi citra Landsat TM8 dengan metode on-screen digitation (Gambar 1) hingga dihasilkan peta tutupan/penggunaan lahan tahun 2013. Peta kesesuaian lahan yang digunakan pada penelitian ini adalah peta kesesuaian untuk lahan basah hasil Regional Physical Planning Program for Transmigration (RePPProT).

Peta kesesuaian lahan basah tersebut menyajikan lahan yang memenuhi kriteria sesuai $(\mathrm{S})$, sesuai bersyarat (\$) dan tidak sesuai $(\mathrm{N})$ untuk pertanian lahan basah yang dalam penelitian ini dianggap memenuhi kriteria untuk sawah. Selanjutnya, peta kesesuaian lahan basah dari RePPProT ditumpang-tindihkan dengan peta RTRWP sehingga didapatkan areal potensial untuk pengembangan padi sawah, berikutnya di overlay lagi dengan Peta Penggunaan Lahan tahun 2013, sehingga dihasilkan Peta Areal Potesial dan Eksisting Pengembangan Padi Sawah tahun 2013 di kabupaten/kota di WP Pesisir Provinsi Kalimantan Barat.

\section{Analisis Wilayah Sektor Basis}

Penentuan wilayah prioritas pengembangan padi sawah didasarkan atas keunggulan komparatif hasil analisis Locational Quotient (LQ) berdasarkan data total luas tanam padi sawah. Untuk melengkapi analisis LQ dilakukan Differential Shift (DS) Analysis dalam ShiftShare Analysis (SSA) untuk menentukan keunggulan kompetitif yang merupakan teknik analisis untuk memahami pergeseran struktur aktivitas. Dalam hal ini produktivitas padi sawah di lokasi penelitian, dibandingkan dengan wilayah provinsi dalam dua titik waktu. Nilai LQ dihitung dengan rumus berikut (Hendayana, 2003);

$$
L Q_{i j}=\frac{X_{i j} / X_{i .}}{X_{. j} / X . .}
$$

Keterangan: $X_{i j}$, nilai luas tanam komoditas ke-j di kabupaten ke-i,; $X_{i}$, total luas tanam semua komoditas di kabupaten ke-i; $X_{. j}$, total luas tanam komoditas ke-j di WP Pesisir; $X$. ,., total luas tanam semua komoditas di WP Pesisir.

Komponen DS dan SSA dihitung berdasarkan persamaan Blakely dan Leigh (2010):

$$
\begin{gathered}
S S A=\left(\frac{X_{. .(t 1)}}{X . .(t 0)}-1\right)+\left(\frac{X_{i(t 1)}}{X_{i(t 0)}}-\frac{X . .(t 1)}{X . .(t 0)}\right) \\
\mathrm{a}
\end{gathered}
$$

Keterangan: a, komponen regional share; b, komponen proportional shift; c, komponen differential shift (DS); X.., total produksi semua komoditas di WP Pesisir; $X_{i}$, total produksi padi sawah di WP Pesisir; Xij, total produksi padi sawah di suatu kabupaten/kota; $\mathrm{t}_{1}$, titik tahun akhir (2011); $\mathrm{t}_{\mathrm{o}}$, titik tahun awal (2008).

\section{Analisis Tipologi Perkembangan Wilayah}

Penentuan tipologi wilayah pengembangan lahan sawah dilakukan dengan mengadopsi ciri kawasan pengembangan pertanian tanaman pangan dalam Peraturan Menteri Pertanian No. 50 tahun 2012 tentang Pedoman Pengembangan Kawasan Pertanian, yang selanjutnya dideskripsikan sebagai acuan pemilihan variabel faktor penciri yang dianalisis. Diawali dengan Factor Analysis (FA), selanjutnya dilakukan Cluster Analysis (CA) untuk mengelompokkan wilayah berciri sama. Tahapan $F A$ meliputi: (1) standarisasi variabel asal, (2) ortogonalisasi variabel dan (3) penyederhanaan jumlah variabel. $C A$ dilakukan berdasarkan jarak Eucledian untuk membatasi wilayah berdasarkan kemiripan karakteristik tertentu dengan prinsip dasar minimalisasi ragam dalam kelompok dan maksimalisasi ragam antar kelompok.

\section{Analisis Kebijakan dan Strategi}

Perencanaan tata ruang strategis menyangkut pengembangan tata ruang wilayah utama yang mungkin timbul pada setiap skala, tetapi lebih detail dari wilayah dan skala nasional (Faludi, 2001). Pada tingkat ini, perencanaan tata ruang strategis biasanya untuk sektor publik yang bertujuan mempengaruhi kegiatan distribusi spasial masa depan (Albrechts, 2004). Perencanaan tata ruang yang dilakukan di wilayah kota dan kabupaten berkaitan dengan tema-tema seperti industri, transportasi, komunikasi, perencanaan penggunaan lahan serta kerjasama dalam produksi dan jasa. Hal ini selain untuk tujuan perencanaan juga berupaya untuk melibatkan pihak yang berwenang, swasta dan masyarakat dalam bentuk kemitraan dalam perencanaan dan pelaksanaan.

Berdasarkan hasil identifikasi lahan potensial, analisis sektor wilayah basis dan unggulan serta tipologi wilayah serta hasil wawancara dengan responden kelompok tani, pengusaha dan tokoh masyarakat setempat, selanjutnya dilakukan analisis kebijakan dan strategi berdasarkan hasil analisis SWOT. Menurut Rangkuti (2009), proses perumusan strategi dapat dilakukan melalui tiga tahap analisis yaitu tahap pengumpulan data, tahap analisis dan tahap pengambilan keputusan. Strategi yang akan diterapkan pada pengembangan masing-masing klaster dalam penelitian ini mengacu pada tiga tahapan tersebut.

\section{HASIL DAN PEMBAHASAN}

\section{Areal Eksisting dan Potensial untuk Pengembangan Padi Sawah}

Hasil rekapitulasi areal eksisting dan potensial menunjukkan ketersediaan 411,950 ha lahan (Tabel 1) untuk pengembangan pertanaman padi sawah, terdiri atas lahan tidur yang menjadi semak atau semak belukar, belukar rawa dan kebun campuran, yang sebagian besar $(>50 \%)$ berada di Kabupaten Sambas dan Kabupaten Ketapang. Lahan yang potensial ini adalah lahan yang penutupan/penggunaan lahannya meliputi semak atau semak belukar, belukar rawa dan perkebunan campuran. 
Tabel 1. Rekapitulasi areal eksisting dan potensial untuk pengembangan lahan sawah berdasarkan penggunaan lahan tahun 2013 di WP Pesisir Provinsi Kalimantan Barat

\begin{tabular}{lrrrrr}
\hline \multirow{2}{*}{ Kabupaten/Kota } & \multicolumn{5}{c}{ Luas (ha) } \\
\cline { 2 - 6 } & $\begin{array}{r}\text { Eksisting } \\
\text { Sawah }\end{array}$ & Potensial & $\begin{array}{r}\text { Potensial } \\
\text { Bersyarat }\end{array}$ & Tidak Potensial & Jumlah \\
\hline Bengkayang & 14,290 & 49,760 & 117,490 & 378,390 & 559,920 \\
Kayong Utara & 18,720 & 21,880 & - & 420,140 & 460,750 \\
Ketapang & 28,210 & 109,420 & - & $2,826,190$ & $2,963,820$ \\
Kubu Raya & 51,160 & 57,670 & 77,940 & 671,050 & 857,820 \\
Pontianak & 16,240 & 36,150 & 1,440 & 145,900 & 199,740 \\
Sambas & 57,010 & 116,720 & 33,690 & 370,090 & 577,510 \\
Singkawang & 3,790 & 20,350 & - & 20,880 & 45,020 \\
\hline Jumlah & 189,420 & 411,950 & 230,560 & $4,832,640$ & $5,664,580$ \\
\hline Persentase (\%) & 3 & 7 & 4 & 85 & 100 \\
\hline
\end{tabular}

\section{Keunggulan Komparatif dan Keunggulan Kompetitif}

Hasil analisis LQ menunjukkan lima kabupaten/kota merupakan wilayah basis (LQ>1) dan dua kabupaten bukan wilayah basis untuk budidaya padi sawah (LQ<1) (Tabel 2). Nilai LQ padi ladang di Kabupaten Bengkayang dan Ketapang mencapai 2.71 dan 3.07 yang menandakan dua kabupaten tersebut juga merupakan wilayah basis pertanaman padi, tetapi untuk jenis padi ladang yang diusahakan di lahan kering atau ladang/tegalan.

Komoditas yang memiliki keunggulan berarti juga memiliki efisiensi finansial (Saptana, 2008). Berdasarkan nilai komponen DS pada tahun 2008 dan 2011 Kabupaten
Kubu Raya, Sambas dan Bengkayang menunjukkan keunggulan kompetitif untuk padi sawah, sedangkan kabupaten lainnya tidak dapat bersaing secara kompetitif (Tabel 3).

Nilai SSA positif untuk padi sawah di tiga kabupaten yaitu Sambas, Bengkayang dan Kubu Raya mencerminkan terjadinya peningkatan produksi padi sawah selama periode tahun 2008-2011 (Tabel 4). Kabupaten lain yang memiliki nilai DS $<0$ juga mempunyai nilai SSA yang negatif, yang artinya terjadi penurunan produksi padi sawah. Hal ini mengindikasikan bahwa budidaya padi sawah kurang berkontribusi terhadap pendapatan daerahnya.

Tabel 2. Nilai LQ berdasarkan luas tanam tanaman pangan tahun 2011 di WP Pesisir Provinsi

\begin{tabular}{lcccccccc}
\hline \multicolumn{1}{c}{ Kab/Kota } & $\begin{array}{c}\text { Padi } \\
\text { Sawah }\end{array}$ & $\begin{array}{c}\text { Padi } \\
\text { Ladang }\end{array}$ & Jagung & Kedelai & $\begin{array}{c}\text { Kacang } \\
\text { Tanah }\end{array}$ & $\begin{array}{c}\text { Kacang } \\
\text { Hijau }\end{array}$ & $\begin{array}{c}\text { Ubi } \\
\text { Kayu }\end{array}$ & $\begin{array}{c}\text { Ubi } \\
\text { Jalar }\end{array}$ \\
\hline Sambas & $\mathbf{1 . 2 3}$ & 0.16 & 0.02 & $\mathbf{2 . 0 6}$ & 0.08 & $\mathbf{3 . 2 5}$ & 0.34 & 0.50 \\
Bengkayang & 0.50 & $\mathbf{2 . 7 1}$ & $\mathbf{3 . 1 2}$ & 0.44 & $\mathbf{2 . 7 8}$ & 0.03 & $\mathbf{1 . 4 2}$ & 0.74 \\
Pontianak & $\mathbf{1 . 2 1}$ & 0.16 & 0.24 & 0.90 & 0.59 & 0.19 & $\mathbf{1 . 2 1}$ & $\mathbf{2 . 2 5}$ \\
Ketapang & 0.92 & $\mathbf{3 . 0 7}$ & 0.13 & 0.08 & $\mathbf{1 . 8 8}$ & 0.07 & $\mathbf{2 . 4 3}$ & $\mathbf{2 . 4 2}$ \\
Singkawang & $\mathbf{1 . 1 7}$ & - & 0.62 & 0.08 & - & - & 0.29 & $\mathbf{4 . 4 0}$ \\
Kayong Utara & $\mathbf{1 . 2 4}$ & 0.13 & 0.03 & 0.06 & 0.30 & 0.01 & $\mathbf{1 . 9 6}$ & 0.75 \\
Kubu Raya & $\mathbf{1 . 1 4}$ & 0.11 & 0.78 & 0.27 & 0.36 & 0.19 & 0.56 & 0.78 \\
\hline
\end{tabular}

Tabel 3. Hasil analisis Differential Shift tanaman pangan berdasarkan produksi periode tahun 2008 dan 2011 di WP Pesisir Provinsi Kalimantan Barat

\begin{tabular}{|c|c|c|c|c|c|c|c|c|}
\hline Kab/Kota & $\begin{array}{c}\text { Padi } \\
\text { Sawah }\end{array}$ & Padi Ladang & Jagung & Kedele & Kacang Tanah & Kacang Hijau & Ubi Kayu & Ubi Jalar \\
\hline Sambas & 0.04 & -0.53 & 0.62 & -0.003 & 0.34 & 1.85 & 0.69 & -0.05 \\
\hline Bengkayang & 0.23 & 0.47 & -0.03 & -0.01 & 0.26 & -3.38 & 0.37 & 0.53 \\
\hline Pontianak & -0.08 & 0.69 & -0.20 & 2.64 & 1.82 & -3.39 & -0.37 & 5.61 \\
\hline Kayong Utara & -0.19 & -0.41 & 2.24 & 0.162 & -0.297 & 0.285 & 1.10 & 0.47 \\
\hline Kubu Raya & 0.01 & -0.47 & 0.24 & -0.206 & -0.342 & -0.048 & -0.31 & -0.52 \\
\hline Prop. Shift & 0.058 & -0.237 & -0.168 & -0.063 & -0.381 & 0.281 & -0.099 & 0.080 \\
\hline
\end{tabular}


Tabel 4. Hasil analisis SSA tanaman pangan berdasarkan produksi periode tahun 2008 dan 2011 di WP Pesisir Provinsi Kalimantan Barat

\begin{tabular}{lcccccccc}
\hline \multicolumn{1}{c}{ Kab/Kota } & $\begin{array}{c}\text { Padi } \\
\text { Sawah }\end{array}$ & $\begin{array}{c}\text { Padi } \\
\text { Ladang }\end{array}$ & Jagung & Kedelai & $\begin{array}{c}\text { Kacang } \\
\text { Tanah }\end{array}$ & $\begin{array}{c}\text { Kacang } \\
\text { Hijau }\end{array}$ & $\begin{array}{c}\text { Ubi } \\
\text { Kayu }\end{array}$ & $\begin{array}{c}\text { Ubi } \\
\text { Jalar }\end{array}$ \\
\hline Sambas & $\mathbf{0 . 0 8}$ & -0.77 & $\mathbf{0 . 4 4}$ & $\mathbf{0 . 4 7}$ & $\mathbf{0 . 2 2}$ & $\mathbf{5 . 0 9}$ & $\mathbf{0 . 4 0}$ & -0.24 \\
Bengkayang & $\mathbf{0 . 2 7}$ & $\mathbf{0 . 2 2}$ & -0.21 & 0.46 & 0.14 & -0.13 & 0.08 & 0.34 \\
Pontianak & -0.04 & $\mathbf{0 . 4 5}$ & -0.37 & 3.11 & 1.70 & -0.14 & -0.66 & 5.42 \\
Ketapang & -0.10 & -0.51 & $\mathbf{0 . 1 2}$ & $\mathbf{1 . 0 0}$ & $\mathbf{0 . 2 9}$ & $\mathbf{0 . 3 3}$ & $\mathbf{0 . 1 7}$ & $\mathbf{0 . 2 7}$ \\
Singkawang & -0.02 & -1.00 & -0.14 & - & - & - & -0.77 & -0.64 \\
Kayong Utara & -0.15 & -0.65 & $\mathbf{2 . 0 6}$ & - & - & - & $\mathbf{0 . 8 1}$ & $\mathbf{0 . 2 8}$ \\
Kubu Raya & $\mathbf{0 . 0 5}$ & -0.71 & $\mathbf{0 . 0 6}$ & -0.19 & -0.77 & -0.89 & -0.60 & -0.71 \\
\hline
\end{tabular}

\section{Tipologi Wilayah}

Dari hasil analisis faktor yang dilanjutkan dengan Cluster Analysis diperoleh pengelompokan wilayah ke dalam tiga tipologi, yaitu berkembang, cukup berkembang dan kurang berkembang (Tabel 5).

Hasil analisis tipologi wilayah yang membagi WP Pesisir ke dalam tiga karakteristik wilayah pengembangan diharapkan akan mempermudah pemerintah daerah untuk mengambil kebijakan teknis terkait pengelolaan sektor pertanian tanaman pangan khususnya padi sawah karena mengkaitkan fungsi hubungan spasial antar wilayah homogen. Hukum Geografi Tobler yang pertama menyebutkan bahwa setiap hal memiliki keterkaitan dengan hal lainnya, namun yang lebih berdekatan memiliki keterkaitan lebih dari lainnya (Rustiadi et al., 2011).

Tabel 5. Hasil analisis klaster tipologi tingkat perkembangan wilayah untuk pengembangan sawah di WP pesisir

\begin{tabular}{cccc}
\hline No. & Klaster & $\begin{array}{c}\text { Tipologi } \\
\text { Wilayah }\end{array}$ & Kabupaten/Kota \\
\hline 1 & I & Berkembang & Sambas dan Kubu Raya \\
\hline 2 & II & $\begin{array}{c}\text { Cukup } \\
\text { Berkembang }\end{array}$ & Bengkayang dan Pontianak \\
\hline 3 & III & $\begin{array}{c}\text { Kurang } \\
\text { Berkembang }\end{array}$ & $\begin{array}{c}\text { Ketapang, Kayong Utara, } \\
\text { dan Singkawang }\end{array}$ \\
\hline
\end{tabular}

Dari tujuh kabupaten/kota yang diklasterkan, hubungan jarak sangat berpengaruh dalam perkembangan aktivitas pertaniannya. Kabupaten yang termasuk tipologi kurang berkembang yaitu Kabupaten Ketapang dan Kayong Utara posisinya paling jauh dari kabupaten/kota lainnya. Hubungan transportasi utama menuju kedua kabupaten tersebut tidak bisa melalui jalan darat, tetapi lewat laut dan udara, sehingga interaksi dengan kabupaten/kota lainnya menjadi lebih rendah. Kecenderungan penggunaan lahan Kota Singkawang adalah untuk pemukiman karena sudah merupakan kota sehingga areal sawah di wilayah tersebut semakin berkurang.

Kabupaten Bengkayang dan Pontianak termasuk dalam wilayah cukup berkembang, yang secara spasial menunjukkan hubungan kedekatan jarak dan saling bertetangga dalam jalur lintasan jalan raya dan antar kecamatan yang banyak terdapat hamparan sawah. Kabupaten yang bertipologi berkembang yaitu Kabupaten Sambas dan Kubu Raya memiliki konfigurasi spasial dengan pola menyebar. Artinya, kedua kabupaten sangat jauh jaraknya. Namun, hamparan sawah di kedua kabupaten tersebut yang terluas karena secara historis keduanya merupakan lumbung padi di Provinsi Kalimantan Barat.

\section{Arahan Pengembangan Kawasan Padi Sawah}

Berdasarkan hasil penilaian sektor wilayah (basis/non basis dan unggulan/non unggulan), pengklasteran tipologi wilayah dan luas lahan tersedia untuk ekstensifikasi sawah diperoleh urutan prioritas sebagaimana disajikan pada Gambar 2 dan Tabel 6.

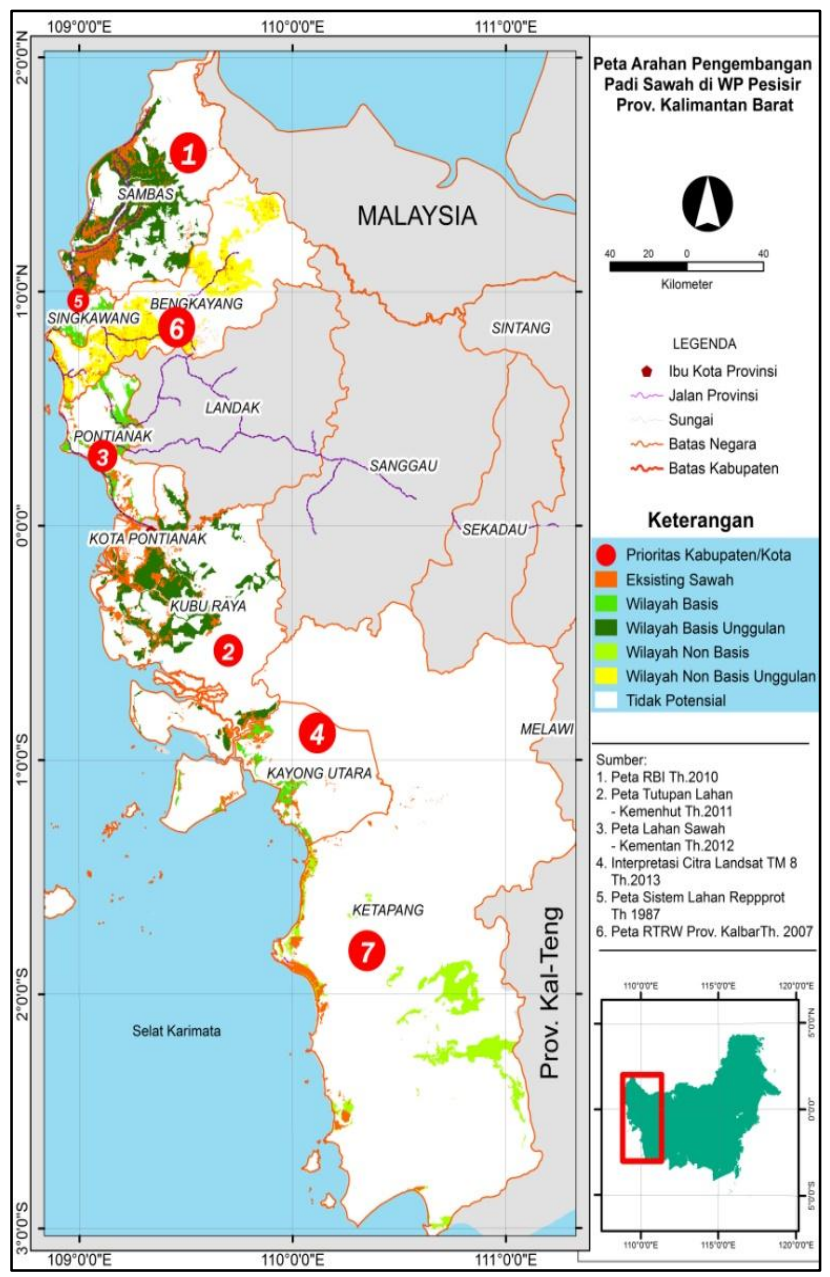

Gambar 2. Peta arahan pengembangan padi sawah 
Tabel 6. Arahan prioritas pengembangan padi sawah di WP pesisir Provinsi Kalimantan Barat

\begin{tabular}{|c|c|c|c|c|c|}
\hline Kabupaten/ Kota & Sektor Wilayah & Tipologi Wilayah & $\begin{array}{c}\text { Tahapan } \\
\text { Pengembangan }\end{array}$ & $\begin{array}{l}\text { Lahan Tersedia } \\
\text { (ha) }\end{array}$ & $\begin{array}{c}\text { Prioritas } \\
\text { Ekstensifikasi }\end{array}$ \\
\hline Sambas & Basis Unggulan & Berkembang & Pemantapan & 116,720 & Prioritas 1 \\
\hline Kubu Raya & Basis Unggulan & Berkembang & Pemantapan & 57,670 & Prioritas 2 \\
\hline Pontianak & Basis & Cukup Berkembang & Pengembangan & 36,150 & Prioritas 3 \\
\hline Kayong Utara & Basis & Belum Berkembang & Pertumbuhan & 21,880 & Prioritas 4 \\
\hline Singkawang & Basis & Belum Berkembang & Pertumbuhan & 20,350 & Prioritas 5 \\
\hline Bengkayang & $\begin{array}{l}\text { Non Basis } \\
\text { Unggulan }\end{array}$ & Cukup Berkembang & Pengembangan & 49,760 & Prioritas 6 \\
\hline Ketapang & Non Basis & Belum Berkembang & Pertumbuhan & 109,420 & Prioritas 7 \\
\hline
\end{tabular}

Penentuan kawasan baru dapat didasarkan pada komoditas yang potensial dan ketersediaan lahan yang sesuai untuk mendukung pengembangan komoditas tersebut (commodity-driven). Ada kalanya lokasi potensial sudah ada, namun belum terdapat komoditas yang layak untuk dikembangkan. Oleh karenanya, dalam pengembangan kawasan pertanian harus ditentukan terlebih dahulu komoditas yang tepat berdasarkan keunggulan komparatif dan kompetitif wilayah.

Menurut Kementerian Pertanian (2012), produktivitas padi yang lebih rendah dari rata-rata provinsi dan pemanfaatan lahan yang belum optimal merupakan ciri kawasan pada tahap "pertumbuhan". Produktivitas padi yang hampir sama dengan produktivitas rata-rata provinsi, pemanfaatan lahan hampir optimal dan mutu hasil belum optimal merupakan ciri kawasan pada tahap "pengembangan". Produktivitas padi yang sudah lebih tinggi dari produktivitas rata-rata provinsi namun mutu hasil belum optimal dan efisiensi usaha belum berkembang adalah ciri dari kawasan pada tahap "pemantapan". Berdasarkan pentahapan ini, maka strategi pengembangan kawasan padi sawah di WP Pesisir didasarkan pada tipologi perkembangan wilayahnya dimaksudkan untuk mengakomodasi keberadaan lahan-lahan sawah eksisting dan lahan potensial untuk pencapaian target swasembada beras.

\section{Strategi Pengembangan Kawasan Padi Sawah}

Perbedaan karakteristik wilayah yang membentuk tiga klaster, yaitu Klaster I (tipologi wilayah belum berkembang, tahap pertumbuhan) Klaster II (tipologi wilayah cukup berkembang, tahap pengembangan) dan Klaster III (tipologi wilayah berkembang, tahap pemantapan), memerlukan strategi pengembangan yang berbeda. Oleh karena itu dilakukan analisis SWOT spesifik klaster (Tabel 7) sebagai dasar pemeringkatan strategi. Strategi dengan prioritas pertama merupakan strategi utama yang dilaksanakan terlebih dahulu, kemudian diikuti prioritas kedua dan ketiga. Arahan strategi ini dimaksudkan untuk menuju terbentuknya kawasan pengembangan yang ideal dan berkelanjutan, hingga terbentuk kawasan pengembangan padi yang terintegrasi.

Tabel 7. Prioritas strategi pengembangan padi sawah per klaster kawasan pengembangan di WP pesisir Provinsi Kalimantan Barat

\begin{tabular}{|c|c|c|c|}
\hline No & Alternatif strategi & Keterkaitan & Prioritas \\
\hline \multicolumn{4}{|c|}{ Klaster I } \\
\hline 1 & $\begin{array}{l}\text { Memanfaatkan potensi_wilayah yang sesuai secara fisik melalui kebijakan pemerintah dengan } \\
\text { pembukaan lahan baru yang berorientasi pada pengembangan padi. }\end{array}$ & $\left(\mathrm{S}_{1235} ; \mathrm{O}_{34}\right)$ & 1 \\
\hline 2 & Peningkatan ketersediaan dan akses teknologi, permodalan, dan penyuluhan. & $\left(\mathrm{S}_{24} ; \mathrm{O}_{126}\right)$ & 2 \\
\hline 3 & Menyediakan jaringan usaha antara gapoktan dengan pihak swasta maupun BUMN. & $\left(\mathrm{W}_{125} ; \mathrm{O}_{15}\right)$ & 3 \\
\hline \multicolumn{4}{|c|}{ Klaster II } \\
\hline 1 & $\begin{array}{l}\text { Memanfaatkan potensi wilayah yang sesuai secara fisik melalui kebijakan pemerintah dengan } \\
\text { pembukaan lahan baru yang berorientasi pada pengembangan padi. }\end{array}$ & $\left(\mathrm{S}_{12357} ; \mathrm{O}_{345}\right)$ & 1 \\
\hline 2 & Peningkatan ketersediaan dan akses teknologi, permodalan, dan penyuluhan. & $\left(\mathrm{W}_{123} ; \mathrm{O}_{245}\right)$ & 2 \\
\hline 3 & $\begin{array}{l}\text { Mendorong peningkatan kualitas dan kuantitas produk dengan penerapan teknologi budidaya dan } \\
\text { pasca panen. }\end{array}$ & $\left(\mathrm{W}_{16} ; \mathrm{O}_{125}\right)$ & 3 \\
\hline \multicolumn{4}{|c|}{ Klaster III } \\
\hline 1 & $\begin{array}{l}\text { Memanfaatkan potensi wilayah yang sesuai secara fisik melalui kebijakan pemerintah dengan } \\
\text { pembukaan lahan baru yang berorientasi pada pengembangan padi. }\end{array}$ & $\left(\mathrm{S}_{123567} ; \mathrm{O}_{12345}\right)$ & 1 \\
\hline 2 & Peningkatan daya saing, industri hilir, pemasaran dan orientasi industri padi. & $\left(\mathrm{S}_{47} ; \mathrm{O}_{1245}\right)$ & 2 \\
\hline 3 & $\begin{array}{l}\text { Meningkatkan peran kelembagaan petani untuk melakukan kemitraan dengan pedagang dan } \\
\text { stakeholder. }\end{array}$ & $\left(\mathrm{W}_{3} ; \mathrm{O}_{1245}\right)$ & 3 \\
\hline
\end{tabular}




\section{SIMPULAN}

1. Lahan tersedia yang dapat dikembangkan untuk pengembangan sawah teridentifikasi seluas 411,960 ha dan lebih dari separuhnya berada di Kabupaten Sambas dan Ketapang.

2. Kabupaten Sambas, Kubu Raya, Pontianak, Kayong Utara, Kabupaten Sambas, Kubu Raya serta Kota Singkawang merupakan wilayah basis dan padi sawah unggul di Kabupaten Sambas dan Kubu Raya.

3. Kabupaten Sambas dan Kubu Raya terklaster ke dalam tipologi wilayah berkembang, Kabupaten Bengkayang dan Pontianak ke dalam wilayah cukup berkembang dan Kabupaten Ketapang, Kayong Utara dan Kota Singkawang ke dalam tipologi wilayah belum berkembang.

4. Prioritas pengembangan sawah yang pertama dan kedua diarahkan ke Kabupaten Sambas dan Kubu Raya, disusul kabupaten lainnya. Strategi prioritas untuk klaster wilayah belum berkembang adalah peningkatan ketersediaan dan akses teknologi, permodalan dan penyuluhan; untuk klaster wilayah cukup berkembang adalah peningkatan kuantitas dan kualitas produk dengan penerapan teknologi budidaya dan pasca panen; dan untuk klaster wilayah berkembang adalah peningkatan daya saing, industri hilir, pemasaran dan orientasi industri padi.

\section{UCAPAN TERIMA KASIH}

Penelitian ini merupakan bagian dari tesis mahasiswa Pasca Sarjana Program Ilmu Perencanaan Wilayah pada Departemen Ilmu Tanah dan Sumberdaya Lahan, Fakultas Pertanian, Institut Pertanian Bogor yang dibiayai oleh beasiswa Bappenas (Pusbinditlakren) tahun 2012.

\section{DAFTAR PUSTAKA}

Albrechts, L. 2004. Strategic (spatial) planning reexamined in: Environment and Planning B. Planning and Design, 32: 743-758.

Blakely, E.J., and N.G. Leigh. 2010. Planning Local Economic Development. Theory and Practice. 4th ed. Sage Publ.
[BPS] Badan Pusat Statistik. 2012. Kalimantan Barat Dalam Angka 2012. Pontianak.

Faludi, A. 2001. The application of the European spatial development perspective: Evidence from the NorthWest Metropolitan area. J. European Planning Studies, 9: 663-675.

Hendayana, R. 2003. Aplikasi metode location quetient (LQ) dalam penentuan komo-ditas unggulan nasional. Informatika Pertanian, 12: 658-675.

Hikmatullah, N. Suharta, dan A. Hidayat. 2008. Potensi sumberdaya lahan untuk pengembangan komoditas pertanian di Provinsi Kalimantan Barat. Jurnal Sumberdaya Lahan, 2: 50-54.

[Kementan] Kementerian Pertanian RI. 2012. Pedoman Pengembangan Kawasan Pertanian. Jakarta.

[Pemprov Kalbar] Pemda Provinsi Kalimantan Barat. 2008. Peraturan Daerah Provinsi Kalimantan Barat Nomor 7 Tahun 2008 tentang Rencana Pembangunan Jangka Menengah Daerah (RPJMD) Provinsi Kalimantan Barat 2008-2013. Pontianak.

Peraturan Menteri Pertanian Nomor 50 tahun 2012 tentang Pedoman Pengembangan Kawasan Pertanian.

Rustiadi, E., S. Saefulhakim, dan D.R. Panuju. 2011. Perencanaan dan Pengembangan Wilayah. Crestpent Press dan Yayasan Pustaka Obor Indonesia. Jakarta.

Rangkuti, F. 2009. Strategi Promosi yang Kreatif dan Analisis Kasus Integrated Marketing Communication. PT. Gramedia Pustaka Utama. Jakarta.

Saptana. 2008. Keunggulan Komparatif-Kompetitif dan Strategi Kemitraan. Pusat Penelitian dan Pengembangan Sosial Ekonomi Pertanian. Badan Penelitian dan Pengembangan Pertanian. Departemen Pertanian RI, Bogor. 